\title{
The home gardens of San Juan Tlacotenco, Tepoztlán, Morelos, as markers of cultural identity
}

\author{
Merit Nefernefer Becerril Tello ${ }^{\text {* }}$
}

Ma. Cristina Saldaña Fernández ${ }^{1}$

Luis Alberto Vargas Guadarrama²

Sergio Moctezuma Pérez ${ }^{3}$

Columba Monroy Ortíz ${ }^{4}$

Alejandro García Flores ${ }^{4}$

\begin{abstract}
In the community of San Juan Tlacotenco, Tepoztlán, Morelos, Mexico, the functions of 20 home gardens were analyzed, focusing on the daily diet of the families, based on their socio-cultural patterns. Information was also obtained about the useful species present. Objective: to determine the production of food plants in home gardens in the community of San Juan Tlacotenco, identifying their cultural reference and context. Methodology: using the ethnographic technique, 20 in-depth interviews and 20 structured interviews were conducted from 2016-2018. Conclusion: the results showed that, in managing species diversity, plants with exchange value are favored for sale, whereas culturally important and desired food plants are conserved for home consumption.
\end{abstract}

Keywords: Home gardens, San Juan Tlacotenco, Tepoztlán

\section{Los huertos familiares de San Juan Tlacotenco, Tepoztlán Morelos, como marcadores de identidad cultural}

\section{Resumen}

En la comunidad de San Juan Tlacotenco, Tepoztlán, Morelos, México, se analizaron las funciones de 20 huertos familiares, enfocadas en la alimentación cotidiana de las familias, con base en sus patrones socioculturales. Además, se obtuvo información sobre las especies útiles, presentes. Objetivo: Determinar la producción de plantas alimentarias de los huertos familiares, en la comunidad de San Juan Tlacotenco, identificando su referente y contexto cultural. Metodología: Mediante la técnica etnográfica se hicieron 20 entrevistas con profundidad y 20 entrevistas estructuradas, entre 2016 y 2018. Conclusión: Los resultados demostraron que, en el manejo de la diversidad de especies, favorece a las plantas con valor de cambio con destino para venta, se conservan para el autoabasto las plantas alimentarias con importancia cultural y apetecidas.

Palabras clave: Huertos familiares, San Juan Tlacotenco, Tepoztlán

\footnotetext{
'Centro de Investigación en Biodiversidad y Conservación, Av. Universidad núm. 1001, Col. Chamilpa, Cuernavaca, Morelos. 'Universidad Nacional Autónoma de México, Instituto de Investigaciones Antropológicas. México. ${ }^{3}$ Instituto de Ciencias Agropecuarias y Rurales. México.

${ }^{4}$ Centro de Investigaciones Biológicas. México.

*Corresponding author: meritbt@hotmail.com Telephone 0445563574706

Received: January 31, 2019.

Accepted: December 10, 2019
} 


\section{Introduction}

To help meet the needs of some rural families, home gardens have been chosen as an option to improve their economic and food situation. In Mexico, it has not been easy for peasant families to cover their basic needs, since they are the most vulnerable group and unprotected by national development policies. Against this background, many families are looking for ways to cover their basic needs, mainly food and others related to subsistence (Pérez, Cuanalo, Sol-Sánchez, 2012:6,7). The study of human nutrition and the different processes of change experienced by various groups of peasants and indigenous people in relation to their food systems, particularly that of home gardens, is undoubtedly a complex issue. Some authors who have influenced rural food studies in Mexico are: HernándezXolocotzi, E. (1976); Vargas and Casillas, (1990); Garine and Vargas, (1997), Nair, (2001), Vargas and Aguilar, (2002), Bertrán, (2005); Kumar and Nair, (2006); Mariaca, González, and Lerner, (2007), Casas, Otero-Arnaiz, PérezNegrón, and Valiente-Banuet (2007). These authors have made important contributions and have considered the sociocultural factors of food in different regions of the world to understand how the most vulnerable population is constituted.

Home gardens constitute an integral basis for the management of natural ecosystems. Their establishment and continuous construction reflect fundamental aspects of the cultural identity of human groups in relation to nature (Cano, de la Tejera, Casas, Salazar, \& García, 2012:14). The results of various studies on this topic conclude that such spaces are important for the life of rural populations, due to the association of plants and animals with multiple uses to satisfy their basic needs. They are a buffer during times of scarcity, and their owners attribute an aesthetic and recreational value to them (Solís, 2013).

In their food and cultural function for families, according to Cahuich (2012), gardens play a prominent role in times of celebration and mark annual harvest cycles (Estrada, Bello, \& Serralta, 1998; Greenberg, 2003; Madrigal \& Pérez, 2005). The place where all these elements come together is in the kitchens of the families, spaces where culinary arts with ritual functions are also practiced, reflecting the cultural identity of the families and their traditional

\section{Introducción}

Para coadyuvar a satisfacer las necesidades de algunas familias rurales, se ha optado por los huertos familiares como opción para mejorar su situación económica y alimenticia. En México, cubrir las necesidades elementales de las familias campesinas no ha sido fácil, ya que son los grupos más vulnerables y desprotegidos por las políticas de desarrollo nacional. Ante este panorama, muchas familias buscan formas para cubrir sus necesidades básicas, principalmente la alimentación y las demás relacionadas con la subsistencia (Pérez, Cuanalo, Sol-Sánchez, 2012:6,7). El estudio de la alimentación humana y los distintos procesos de cambio que experimentan los diversos grupos de campesinos e indígenas en relación con sus sistemas alimentarios, en particular, la de los huertos familiares, es sin duda un tema complejo. Algunos autores que han influido en los estudios de la alimentación rural en México son: HernándezXolocotzi, E. (1976); Vargas y Casillas, (1990); Garine y Vargas, (1997), Nair, (2001), Vargas y Aguilar, (2002), Bertrán, (2005); Kumar y Nair, (2006); Mariaca, González, y Lerner, (2007), Casas, Otero-Arnaiz, PérezNegrón, y Valiente-Banuet (2007). Estos autores han hecho contribuciones importantes y han ponderado los factores socioculturales de la alimentación en distintas regiones del mundo, para entender cómo se constituye la población más vulnerable.

Los huertos familiares constituyen una base integral del manejo de los ecosistemas naturales, su establecimiento y continua construcción reflejan aspectos fundamentales de la identidad cultural, de los grupos humanos en relación con la naturaleza (Cano, de la Tejera, Casas, Salazar, \& García, 2012:14). Los resultados de diversas investigaciones sobre este tema concluyen que dichos espacios son importantes para la vida de las poblaciones rurales, debido a la asociación de plantas y animales con usos múltiples para satisfacer sus necesidades básicas. Son un amortiguamiento durante las épocas de escasez, además, sus propietarios les atribuyen un valor estético y recreativo (Solís, 2013).

En su función alimentaria y cultural para las familias, de acuerdo con Cahuich (2012) los huertos juegan un lugar destacado en épocas de fiesta $y$ marcan ciclos anuales de cosecha (Estrada, Bello, \& Serralta, 1998; Greenberg, 2003; Madrigal \& Pérez, 
knowledge of plants and ecosystems. Food is prepared with products from the home gardens, a process passed down from mothers to daughters, from one generation to the next; they are the bearers of this learning and responsible for its transmission to younger women.

The municipality of Tepoztlán has its own history in which it has been able to solve its subsistence problems over time. In Lewis' work (1968) Antropología de la pobreza (Anthropology of Poverty), he describes the community's agricultural resources as limited and scarce; however, he highlights the inhabitants' in-depth knowledge of their physical environment, exemplified by their crop rotation agriculture and extensive knowledge of the benefits of fallow land. We once again return to Lewis' work, as it provides references on which vegetables, fruits and herbs were grown and consumed in the community and thus have a basis for comparison with the current gardens.

The subsistence strategies of the peasant groups are diverse, including the marketing of products that they cultivate, handicrafts, and the sale of their wage labor in construction projects; however, these are not their only sources for obtaining resources (Mariaca et al., 2007). The role of the gardens is important because only in them are native plants and others from various regions found that have been used as food for families, especially those that have been part of the collective and ancestral memory of the communities of indigenous origin, which has allowed the groups to strengthen their identity, knowing where they come from and how their culture, their landscapes, and their habitat have been consolidated, because there are processes behind all the food that have allowed them to survive over time (Mariaca et al., 2007).

On certain occasions, home gardens have undergone a process of change due to the preferences of the families, which jeopardizes their permanence in peasant homes. Families have a memory associated with their food traditions, which is reflected in daily activities, especially among women who have this knowledge for food production, which they have acquired from past generations, for the care of their family and health, as well as the transmission of knowledge about the environment and practices and uses related to it (Cano, 2015).
2005). El lugar donde se conjugan todos estos elementos es en las cocinas de las familias, espacios donde también se elaboran artes culinarias con funciones rituales, que reflejan la identidad cultural de las familias y su conocimiento tradicional de las plantas y de los ecosistemas. La preparación de alimentos se hace con productos provenientes de los huertos familiares, proceso heredado de madres a hijas, de una generación a otra, ellas son portadoras de este aprendizaje y responsables de su transmisión a las mujeres más jóvenes.

El municipio de Tepoztlán cuenta con una historia propia en la que ha podido solucionar sus problemas de subsistencia a lo largo del tiempo. En el trabajo de Lewis (1968) Antropología de la pobreza, describe que los recursos agrícolas de la comunidad son limitados y escasos; sin embargo, subraya el alto conocimiento del medio físico por sus pobladores, quienes cuentan con una agricultura de rotación de cultivos y conocen ampliamente los beneficios de la tierra de barbecho. Retomamos el trabajo de Lewis, ya que aporta referencias sobre qué vegetales, frutas y hierbas se cultivaban y consumían en la comunidad y de esta manera contar con un eje de comparación de los huertos actuales.

Las estrategias de subsistencia de los grupos campesinos son diversas, incluyendo la comercialización de productos que cultivan, las artesanías, la venta de la fuerza de trabajo en obras de construcción, sin embargo, éstas no son las únicas fuentes para la obtención de recursos (Mariaca et al., 2007). El papel de los huertos es importante debido a que solo en ellos se encuentran plantas nativas y otras provenientes de diversas regiones que han sido usadas como alimento para las familias, sobre todo, que han sido parte de la memoria colectiva y ancestral de las comunidades de origen indígena, lo cual ha permitido afianzar la identidad de los grupos, saber de dónde vienen y cómo ha sido consolidada su cultura, sus paisajes, su hábitat, porque existen procesos detrás de todos los alimentos que les han permitido sobrevivir a lo largo del tiempo (Mariaca et al., 2007).

En ciertas ocasiones, los huertos familiares han sufrido un proceso de cambio debido a las preferencias de las familias, lo cual compromete su permanencia en las viviendas campesinas. Las familias cuentan con una memoria asociada con sus tradiciones alimenta- 
From in-depth interviews conducted with 20 families that own gardens, it was possible to know and understand the current situation of their gardens, their family life stories and their preferences. During the fieldwork, these families indicated that in the 1940s and 1950s, they had a greater diversity and abundance of food that they grew, such as coffee, mango, fodder oats, gourd, prickly pears, bananas, plums, criollo beans, huauzontle and peas, which they could consume throughout the year. Photos 1 and 2 show the plant preferences of the owners of the home gardens of San Juan Tlacotenco.

\section{Materials and methods}

\section{Study Site}

San Juan Tlacotenco is located within the polygon of the Ajusco-Chichinautzin Biological Corridor; the town is built above the longest lava tube system in rias, que se refleja en las actividades cotidianas, sobre todo, entre las mujeres quienes cuentan con ese conocimiento para la producción de alimentos, mismo que han adquirido de generaciones pasadas, para el cuidado de la familia, de la salud y la transmisión de conocimiento del entorno, de las prácticas y del aprovechamiento del ambiente (Cano, 2015).

A partir de las entrevistas a profundidad realizadas a 20 familias propietarias de huertos, fue posible conocer y comprender la situación actual de sus huertos, sus historias de vida familiar y sus preferencias. Durante el trabajo de campo, estas familias indicaron que en la década de los años cuarenta y cincuenta, contaban con mayor diversidad y abundancia de alimentos que ellos cultivaban, como café, mango, avena forrajera, guaje, tunas, plátano, ciruelas, frijol criollo, huauzontle y chícharo, que podían consumir durante el año. En las Fotos 1 y 2 se muestran las preferencias de plantas de los huertos de San Juan Tlacotenco.

Figure 1. Ixtlahuca valley, State of Mexico.

Figura 1. El valle de Ixtlahuca, Estado de México.

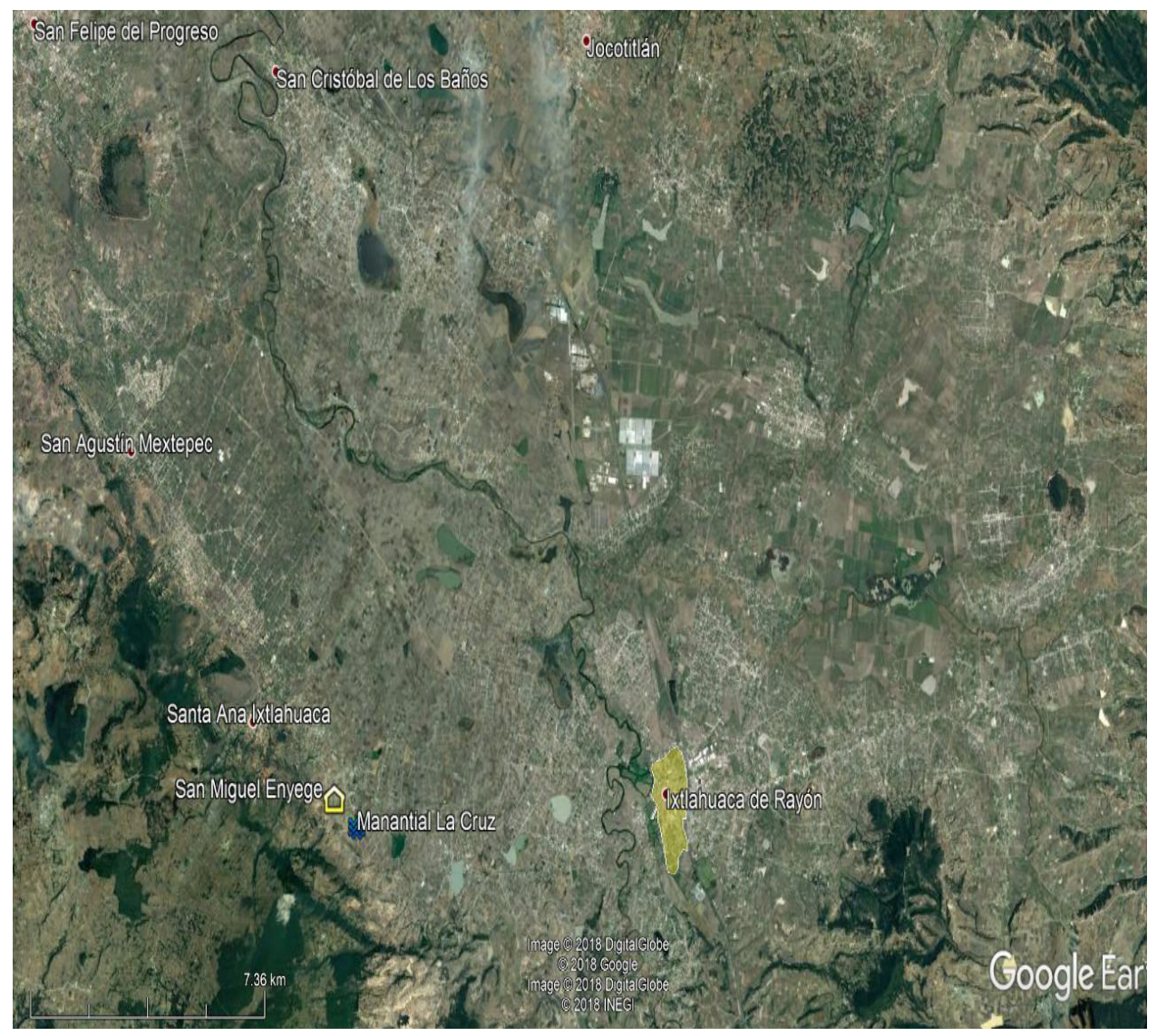

Source: Google Earth 2018 Fuente: Google Earth 2018. 


\section{Contrast of plant preferences/Contraste de preferencias en plantas}

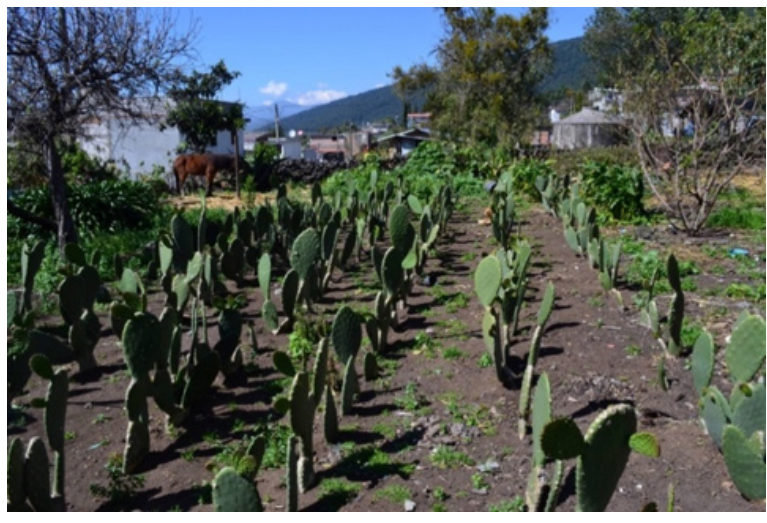

Photo 1. Home garden with food plants.

Foto 1. Huerto familiar con plantas alimentarias.

Source: 2016-2018 fieldwork Fuente: Trabajo de campo 2016-2018

Continental America: the Tlacotenco system. This Nahuatlato town has about 1068 inhabitants and is located in a mountainous area in the municipality of Tepoztlán, Morelos, at 19०00'59" $\mathrm{N}$ and $99^{\circ} 05^{\prime} 36^{\prime \prime} \mathrm{W}$ at an elevation of $2369.32 \mathrm{~m}$ (Programa de Manejo del Parque Nacional el Tepozteco, 2018). Figures 1 and 2 show the geographical location of the study community.

\section{Methodological planning}

The design of the research and information gathering was exploratory, with a methodological strategy that favors qualitative analysis. This methodology focuses on social phenomena from the perspective of the actor, and aims to investigate what people perceive as relevant, seeking to understand the motives and beliefs behind their actions. The information gathering techniques were open and structured interviews, conducted with 20 informants to learn about the conditions of their home garden. The purpose of the in-depth interview was to achieve an interaction between interviewer and interviewee, where the interviewer asked a series of questions to the person interviewed in order to obtain information on specific aspects (Robles, 2011); the visual record was obtained under the consent of the families selected at random for this study in San Juan Tlacotenco.

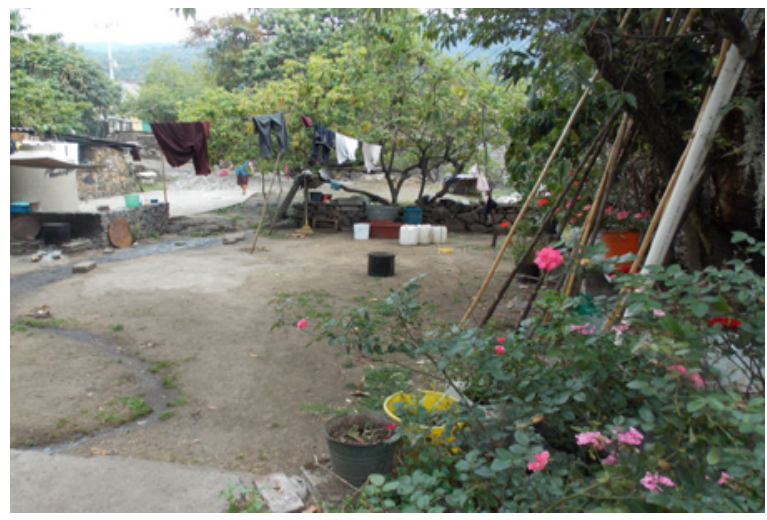

Photo 2. Home garden with ornamental plants.

Foto 2. Huerto familiar con plantas de ornato.

Source: 2016-2018 fieldwork Fuente: Trabajo de campo 2016-2018

\section{Materiales y métodos}

\section{Sitio de Estudio}

San Juan Tlacotenco, se encuentra dentro del polígono del Corredor Biológico AjuscoChichinautzin, bajo sus tierras alberga al sistema de tubos de lava más largo de América Continental: el sistema Tlacotenco. Este pueblo nahuatlato cuenta con unos 1068 habitantes, está ubicado en un área montañosa en el municipio de Tepoztlán, Morelos, a los $19^{\circ} 00^{\prime} 59^{\prime \prime}, \mathrm{LN}$ y $99^{\circ} 05^{\prime} 36^{\prime \prime} \mathrm{LO}$ y una altitud de 2 $369.32 \mathrm{~m}$ (Programa de Manejo del Parque Nacional el Tepozteco, 2018). En las Figuras 1 y 2, se muestra la ubicación geográfica de la comunidad de estudio.

\section{Planeación metodológica}

El diseño de la investigación y obtención de información fue exploratorio, con una estrategia metodológica que privilegia el análisis cualitativo. Esta metodología enfoca los fenómenos sociales desde la perspectiva del actor, y se propone indagar sobre aquello que las personas perciben como relevante, buscando comprender los motivos y creencias que están detrás de sus acciones. Las técnicas de recolección de información fueron: entrevistas abiertas y estructuradas, realizadas a 20 informantes para conocer las condiciones de su huerto familiar, el propósito de la entrevista a profundidad fue lograr una interacción entre entrevistador y entrevistado, 
Figure 1 and 2. Location of the community of San Juan Tlacotenco.

Figura 1 y 2. Ubicación de la comunidad de San Juan Tlacotenco.

\section{San Juan Tlacotenco, Tepoztlán}
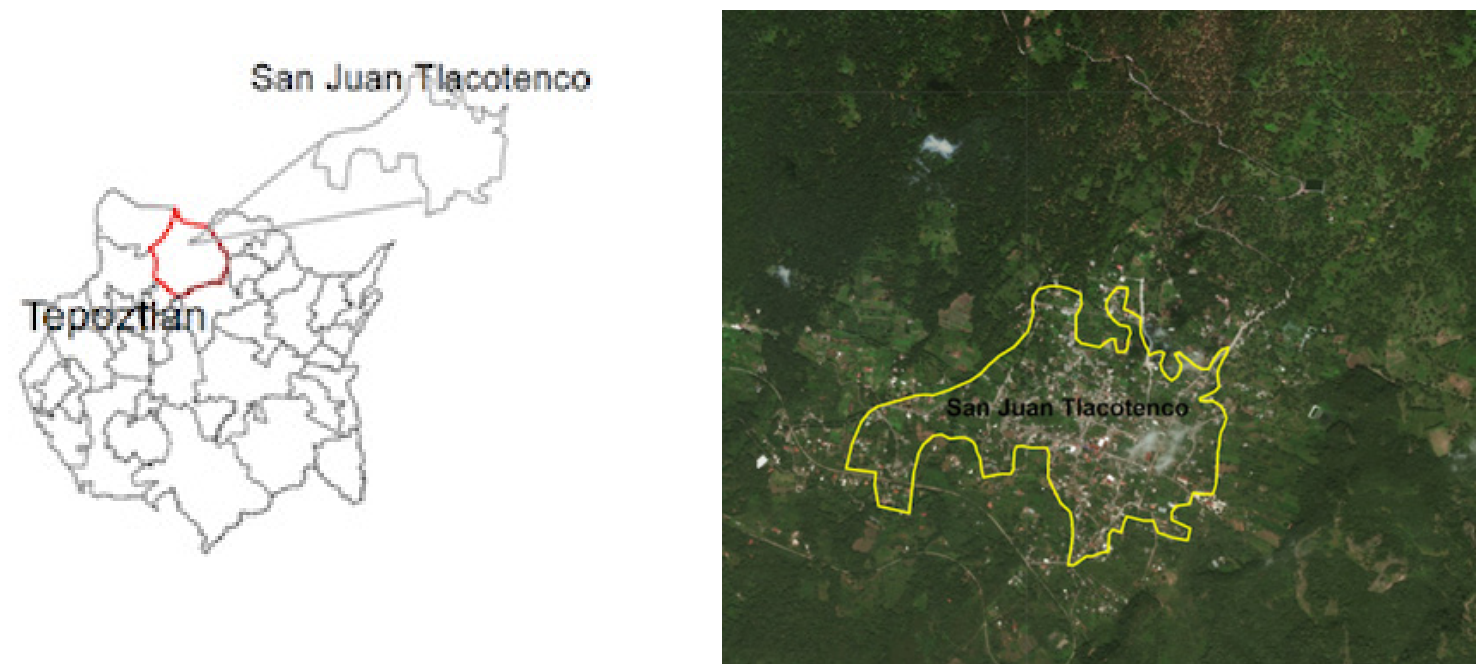

Source: Laboratorio Interdisciplinario de Sistemas de Información Geográfica. Prepared by: LISIG manager Dr. Valentino Sorani and Oscar A. Aragón Gaspar. Fuente: Laboratorio Interdisciplinario de Sistemas de Información Geográfica. Elaborado por: Encargado de LISIG, Dr. Valentino Sorani y Oscar A. Aragón Gaspar.

\section{Results and discussion}

\section{Food as a motivational and cultural marker}

The home gardens of San Juan Tlacotenco are an element anchored in the community's culture because its traditions interact with its agricultural activity, based on the milpa, nopal cultivation and grazing. Through home gardens this community has preserved its cultural identity and local traditions. The qualitative data obtained show how people associate their sense of belonging to preserve the pleasure for and cultural value of some foods, since they preserve them to maintain a link with their cultural identity (Solís, 2013).

In this sense, Cano (2015) states that food becomes a fundamental part of the culture of communities. Reliance on edible natural resources, technological development and culinary inventiveness have evolved and influenced what is consumed, from how it is obtained to how food is prepared.

Eating is a biological necessity on which humanity depends, from the anthropological point of view it is analyzed through social/cultural expression, from its significant elements in the field of systems and processes related to the entire process, as a set of social actions (Aguilar, 2014). Food and the act of eating are much en donde el entrevistador, realizó una serie de preguntas a la persona entrevistada con el fin de obtener información sobre aspectos específicos (Robles, 2011), el registro visual fue obtenido bajo el consentimiento de las familias seleccionadas al azar para este estudio en San Juan Tlacotenco.

\section{Resultados y discusión}

\section{La alimentación como marcador motivacional y cultural}

Los huertos familiares de San Juan Tlacotenco, son un elemento anclado en la cultura de la comunidad, debido a que sus tradiciones interactúan con su actividad agrícola; basada en la milpa, cultivo de nopal y pastoreo. Mediante los huertos familiares esta comunidad ha preservado su identidad cultural y sus tradiciones locales. Los datos cualitativos obtenidos muestran cómo las personas asocian su sentido de pertenencia, para conservar el gusto y valor cultural de algunos alimentos, ya que los conservan para mantener un lazo con su identidad cultural.

Por esta razón, los huertos familiares son percibidos como marcadores de identidad cultural (Solís, 2013).

En este sentido Cano (2015), refiere que la alimentación se convierte en parte fundamental 
more than sustenance for the body; they are a pleasant stimulus for the senses, an instrument of communication, of social bonding and a means of cultural expression. The idea that a population has about food is reflected in the meaning attributed to it, forming a classification system that regulates food choice according to the occasion, condition, sex and social status (Pérez, 2011).

The first element that revolves around food is the act of consuming culinary preparations that should be analyzed as a complex fact, and with different meanings depending on the culture being analyzed. In this way, it is the cuisine where the practices and knowledge that are part of the cultural heritage and identity are specified (Álvarez, Olguín, Asiain, Alcántar, \& Castillo, 2001). Most of the world's peoples have their own cuisine, where the products used to prepare it are defined and to which values and sentimental and emotional ties are attributed. This action is described by Claude Lévi-Strauss in his work The raw and the cooked (1964), where he proposed the different changes caused in food when cooking, fermenting and transforming it; therefore, this process is introduced into the fields of universal cuisine present in any society.

Food transformation is perhaps one of the processes where we see how quickly the relationship between society/nature and technology/culture is modified (Meléndez \& Cañez, 2009). The home kitchen is the space where inherited knowledge about what is cooked and how food is cooked is developed, a place where a symbolic baggage that expresses people's culture is expressed (Lévi-Strauss, 1964).

\section{Home garden support strategy}

The home gardens of San Juan Tlacotenco are part of the housing spaces and cultural component of families; several plants are found there, with different life forms, management and use categories (Martínez, 2005). Home gardens provide, during the annual seasons, food and plants that provide them with various benefits, which are used according to the circumstances and needs of the families.

These systems are managed, mainly in rural areas, by families of peasant origin that are in gradual processes of transformation and influenced mainly de la cultura de las comunidades. La dependencia de los recursos naturales comestibles, el desarrollo tecnológico y la inventiva culinaria, han evolucionado e incidido en lo que se consume, desde cómo se obtiene, hasta cómo se preparan los alimentos.

La alimentación que es necesidad biológica de la cual depende la humanidad, desde la óptica antropológica es analizada a través de la expresión social/cultural, desde sus elementos significativos en el ámbito de los sistemas y procesos relacionados con la totalidad de su proceso, en tanto conjunto de acciones sociales (Aguilar, 2014). La alimentación y el acto de comer son mucho más que un sustento para el cuerpo, son un estímulo placentero para los sentidos, instrumento de comunicación, de vinculación social y medio de expresión cultural. La idea que tiene una población sobre los alimentos se refleja en el significado que se le atribuye, conformando un sistema de clasificación que regula la elección alimentaria según la ocasión, condición, sexo y estatus social (Pérez, 2011).

El primer elemento que gira en torno a la alimentación, es el acto de consumir las preparaciones culinarias y que debe analizarse como un hecho complejo, y de diversos significados dependiendo la cultura que se analice. De esta manera, es la cocina en donde se concretan las prácticas y saberes que son parte de la herencia e identidad cultural (Álvarez, Olguín, Asiain, Alcántar, \& Castillo, 2001). La mayoría de los pueblos del mundo cuentan con una cocina propia, donde se definen los productos que se emplean para ser preparados a los que se les atribuyen valores, lazos sentimentales y afectivos, esta acción es descrita en el trabajo realizado por Claude Lévi- Strauss en su obra, Lo crudo y lo cocido (1964), donde propuso los distintos cambios provocados en la comida al cocer, fermentar y transformar los alimentos, se introduce en terrenos de la cocina universal presente en cualquier sociedad.

La transformación alimentaria, es quizá uno de los procesos donde vemos expresada la rapidez con la que se modifica la relación sociedad/naturaleza y tecnología/cultura (Meléndez \& Cañez, 2009). La cocina de los hogares, es el espacio donde se desarrolla este conocimiento (Lévi-Strauss, 1964), lo que se cocina y como se cocina, ofrece información 
by urbanization, the change in the space's use and migration (Cano, et al., 2012). Despite this eminent transformation that the use and diversity of plants is undergoing, they are used by families as a strategy to complete the daily diet.

The gardens of San Juan Tlacotenco offer diverse benefits to their owners. During the fieldwork, the diversity of the gardens was noticed; for example, it was observed that some had a preference for food plants, and others for medicinal or ornamental plants.

Twenty home gardens were analyzed using a differentiation of the gardens; only those containing a greater number of species for food purposes were taken into account. Table 1 below shows the most representative gardens in terms of use and consumption of food plants.

Regarding the care and management of the home gardens in San Juan Tlacotenco, it was observed that there is a division of labor in those gardens where several family members are involved. Older and younger men are responsible for doing the heaviest work such as weeding the garden, making compost, pruning trees in the rainy season, removing the earth, and fertilizing. Not all men participate in the care and management of the gardens we observed. Women participate the most and they do all the aforementioned activities alone, in addition to the transfer of plants, which is often done using recycled containers such as broken buckets, metal pots, and PET bottles; children also participate in these activities by generally helping their mothers and by collecting ripe fruits or herbs.

The role of women within traditional families is very clear. There is historical background on the role of women in terms of how they use and identify various medicinal plants, since health plays an important role in family wellbeing; in addition, women are in charge of and responsible for family care and food preparation (Cruz, 2016).

Table 2 provides detailed data on those responsible for the care and management of the home garden. Of the 20 gardens sampled, only those with the highest production of food plants were selected. sobre el contexto y condición socioeconómica de quienes realizan esta actividad, la cocina no es ajena a la significación que se les da a los alimentos, en las diversas situaciones para las cuales se prepara la comida; las comunidades tradicionales como sus huertos familiares, son los herederos de todo este bagaje simbólico, donde vemos expresada la cultura de las comunidades.

\section{Estrategia de sustento de los huertos familiares}

Los huertos familiares de San Juan Tlacotenco, son parte de los espacios de la vivienda y componente cultural de las familias, allí se encuentran diversas plantas, con distintas formas de vida, manejo y categorías de usos (Martínez, 2005). Los huertos familiares proveen durante las estaciones anuales, alimentos y plantas que les proporcionan diversos beneficios, que son aprovechados según las circunstancias y necesidades de las familias.

Estos sistemas son manejados, principalmente en las zonas rurales, por familias de origen campesino que están en procesos paulatinos de transformación e influenciados principalmente por la urbanización, el cambio de vocación del espacio y la migración (Cano, et al., 2012). A pesar de esta eminente trasformación que está sufriendo el aprovechamiento y diversidad de plantas, son utilizadas por las familias, las cuales representan una estrategia para completar la dieta diaria.

Los huertos de San Juan Tlacotenco, ofrecen diversos beneficios a sus propietarios, durante el trabajo de campo se distinguió la diversidad de huertos, por ejemplo, se observó que algunos contaban con preferencias en plantas alimentarias, y otros por plantas medicinales u ornamentales.

Se analizaron 20 huertos familiares, donde se empleó una discriminación de los huertos, se tomaron en cuenta solo aquellos, que contenían un mayor número de especies con fines alimentarios. A continuación, en la Cuadro 1 se muestran los huertos más representativos en uso y consumo de plantas alimentarias.

Respecto al cuidado y manejo de los huertos familiares de San Juan Tlacotenco, se observó que en aquellos huertos donde intervienen varios integrantes de la familia, existe una división del trabajo. Los hombres mayores y jóvenes son los 
Table 1. Outstanding home gardens in food plant production.

Cuadro 1. Huertos familiares sobresalientes en producción de plantas alimentarias.

\begin{tabular}{|c|c|c|c|c|c|c|c|c|c|c|c|c|c|}
\hline $\begin{array}{l}\text { Scientific name/ } \\
\text { Nombre científico }\end{array}$ & $\begin{array}{l}\text { Common name } \\
\text { Nombre común }\end{array}$ & HF1 & HF2 & HF3 & HF4 & HF5 & HF6 & HF7 & HF8 & HF9 & HF10 & HF11 & HF12 \\
\hline Anona cherimola & Chirimoya & -- & 1 & -- & -- & 1 & -- & -- & -- & -- & -- & -- & -- \\
\hline Apium graveolens & Celery / Apio & -- & -- & -- & -- & -- & -- & -- & -- & -- & -- & 20 & -- \\
\hline Beta vulgaris & Beet / Betabel & -- & -- & -- & -- & -- & -- & 1 & -- & -- & -- & 25 & -- \\
\hline Capsicum pubescens & $\begin{array}{l}\text { Tree pepper/ } \\
\text { Chile manzano }\end{array}$ & -- & 1 & -- & -- & 1 & 3 & 5 & 1 & -- & 1 & 7 & -- \\
\hline Casimiroa edulis & $\begin{array}{l}\text { White sapote/ } \\
\text { Zapote blanco }\end{array}$ & -- & 5 & -- & -- & -- & -- & 2 & 1 & 1 & -- & 1 & 1 \\
\hline Citrus reticulata & $\begin{array}{l}\text { Mandarin/ } \\
\text { Mandarina }\end{array}$ & -- & -- & -- & 6 & -- & 1 & -- & -- & -- & -- & -- & -- \\
\hline Citrus sinensis & Orange/Naranja & -- & 2 & 1 & 1 & -- & -- & 1 & -- & -- & -- & -- & 1 \\
\hline Citrus latifolia & Lemon/Limón & -- & 2 & -- & 1 & -- & 3 & -- & 1 & -- & -- & -- & -- \\
\hline Crataegus mexicana & Tejocote & 3 & 4 & 11 & 4 & 2 & -- & -- & -- & 4 & -- & -- & 13 \\
\hline Cucurbita ficifolia & $\begin{array}{l}\text { Fig-leaf gourd/ } \\
\text { Chilacayote }\end{array}$ & -- & 2 & -- & 2 & -- & -- & -- & 1 & -- & -- & 6 & 7 \\
\hline Cucurbita pepo & Squash/Calabaza & -- & -- & -- & -- & -- & -- & -- & -- & -- & -- & -- & -- \\
\hline Eriobotryajaponica & Loquat/Nispero & -- & 7 & -- & -- & 1 & -- & 4 & 1 & 2 & 2 & 6 & 2 \\
\hline Ficus carica & Common fig/Higo & -- & 1 & -- & -- & & -- & -- & -- & -- & & -- & -- \\
\hline Fragaria chiloensis & Strawberry/Fresa & -- & -- & 1 & -- & 6 & 1 & -- & -- & -- & 1 & -- & -- \\
\hline Hylocereus undatus & Pitahaya/Pitaya & -- & -- & -- & -- & -- & -- & -- & -- & -- & -- & -- & -- \\
\hline Ingajinicuil & $\begin{array}{l}\text { Ice cream bean/ } \\
\text { Cajenecuil }\end{array}$ & -- & 1 & -- & 1 & -- & 1 & 2 & -- & -- & -- & & -- \\
\hline Ipomea batata & $\begin{array}{l}\text { Sweet potato / } \\
\text { Camote }\end{array}$ & -- & -- & 1 & -- & -- & -- & -- & -- & -- & -- & 5 & -- \\
\hline Malus domestica & Apple/Manzana & -- & -- & -- & -- & -- & -- & -- & -- & -- & -- & -- & -- \\
\hline Mangifera indica & Mango & -- & -- & -- & -- & -- & -- & -- & -- & -- & -- & 5 & -- \\
\hline Morus celtidifolia & $\begin{array}{l}\text { Texas mulberry/ } \\
\text { Mora }\end{array}$ & 6 & 24 & -- & 1 & 2 & -- & -- & 1 & -- & 1 & -- & -- \\
\hline Morus nigra & $\begin{array}{l}\text { Black mulberry/ } \\
\text { Mora }\end{array}$ & -- & -- & -- & -- & -- & -- & -- & -- & -- & -- & -- & -- \\
\hline Musa paradisiaca & Banana/Platano & -- & -- & -- & -- & -- & -- & -- & -- & -- & -- & 5 & -- \\
\hline Pasiflora edulis & $\begin{array}{l}\text { Passion fruit / } \\
\text { Maracuyá }\end{array}$ & 1 & -- & -- & -- & -- & -- & -- & -- & -- & -- & -- & -- \\
\hline Lactuca sativa & Lettuce/Lechuga & 4 & -- & -- & -- & -- & -- & -- & -- & -- & -- & -- & -- \\
\hline Opuntia ficus-indica & Nopal & 4 & 181 & 15 & 9 & -- & 3 & 2 & 108 & 10 & 30 & 1000 & 176 \\
\hline Passiflora ligularis & $\begin{array}{l}\text { Granadia/ } \\
\text { Granada China }\end{array}$ & -- & -- & -- & -- & -- & -- & -- & -- & -- & -- & 1 & -- \\
\hline Persea americana & Avocado/Aguacate & -- & -- & -- & -- & 1 & -- & -- & -- & -- & -- & 2 & -- \\
\hline Phaseolus vulgaris & $\begin{array}{l}\text { Common bean/ } \\
\text { Frijol peruano }\end{array}$ & 1 & 1 & 1 & 1 & 6 & 3 & 2 & -- & 1 & 1 & 8 & 1 \\
\hline Prunus persica & Peach / Durazno & -- & 1 & -- & -- & -- & -- & -- & -- & -- & -- & 12 & -- \\
\hline $\begin{array}{l}\text { Prunus serótina subsp. } \\
\text { capulli }\end{array}$ & $\begin{array}{l}\text { Black cherry/ } \\
\text { Capulin }\end{array}$ & 4 & 29 & 10 & 7 & 2 & 5 & 7 & 1 & 5 & 4 & 12 & 17 \\
\hline Punica granaatum & $\begin{array}{l}\text { Pomegranate/ } \\
\text { Granada roja }\end{array}$ & -- & 2 & 1 & -- & -- & -- & -- & -- & 1 & -- & 1 & 1 \\
\hline Pyrus communis & Pear/Pera & -- & 1 & -- & -- & 1 & -- & -- & -- & 1 & -- & 4 & -- \\
\hline Raphanus sativus & Radish/Rabano & 5 & -- & -- & -- & -- & -- & -- & 3 & -- & -- & -- & -- \\
\hline Rubus adenotrichus & $\begin{array}{l}\text { Blackberry/ } \\
\text { Zarzamora }\end{array}$ & -- & -- & -- & -- & -- & -- & -- & -- & -- & -- & 30 & -- \\
\hline Rubusidoeus & $\begin{array}{l}\text { Raspberry / } \\
\text { Frambuesa }\end{array}$ & 1 & 10 & 1 & 1 & 3 & -- & -- & -- & -- & -- & 8 & -- \\
\hline Sechium edule & Chayote & -- & -- & -- & -- & -- & -- & -- & -- & -- & -- & -- & -- \\
\hline Solanum tuberosum & Potato/Papa & -- & -- & 1 & -- & -- & -- & -- & -- & -- & -- & 5 & -- \\
\hline Spondias purputea & Plum/Ciruela & -- & -- & -- & -- & 7 & -- & -- & -- & -- & -- & -- & -- \\
\hline Taraxcum sp & $\begin{array}{l}\text { Dandelion/Prima } \\
\text { del diente de león }\end{array}$ & -- & -- & -- & -- & 2 & -- & -- & 5 & -- & -- & -- & 5 \\
\hline Vicia faba & Broad bean/Aba & -- & -- & -- & -- & 1 & -- & -- & -- & -- & -- & 26 & -- \\
\hline \multirow[t]{2}{*}{ Zea mays } & $\begin{array}{l}\text { Criollo corn/ } \\
\text { Maíz criollo }\end{array}$ & -- & -- & -- & -- & -- & -- & -- & -- & 3 & -- & 44 & -- \\
\hline & & 29 & 275 & 43 & 34 & 36 & 20 & 26 & 123 & 28 & 40 & 1233 & 224 \\
\hline
\end{tabular}

Source: Author-made based on fieldwork/Fuente: Elaboración propia a partir del trabajo de campo 
Taking as a reference the in-depth interviews, information was obtained that allowed us to build the life history of our informants and determine the use of plant species. The products obtained from the home garden contribute to self-sufficiency and reduce the need to buy products.

Despite being a community of peasant origin, our informants have different occupations and jobs:

Informant, HG3: Young married couple from San Juan Tlacotenco with a 7-year-old daughter. They have a bachelor's degree in nursing and work for the IMSS in Cuernavaca in the emergency department.

Informant, HG 4: Informant is originally from San Juan Tlacotenco, is 26 years old and has finished high school. She recognizes several words in Nahuatl but does not speak it in its entirety. She currently has a small business at the entrance to her house where she sets up a table on which she puts various sweets, water, sweet drinks, soft drinks, popcorn and chicharrones (pork rinds), colored pencils, and toys that elementary school children buy. She is the younger of 2 siblings; her older brother is studying a bachelor's degree in agriculture at UAEM. Their parents and grandparents live in the same house.

The reasons for having a home garden are: cultural heritage, obtaining food and the various uses that the owners get, which respond to the needs of each family; we find gardens with crops intended for sale and valued for the ornamental characteristics of their flowers, and others valued for their food production.

Informant HG 19: The family has farmland in the mountains, where they plant various products: potatoes, corn, beans, broad beans, nopal, and fodder oats. They also raise black-headed sheep (sulfo) that they sell as meat, they have dairy cows from which they extract milk that they sell, and they have three apiaries, with two containing 30 bee boxes each and the other with 20; they collect honey three times a year, first in April, then in November and finally in December. The garden provides the family with diverse products throughout the year. The family uses these products to feed themselves, and the surplus is put up for sale in the municipal capital of Tepoztlán on encargados de realizar el trabajo más pesado como desyerbar el huerto, elaborar la composta, podar los árboles en época de lluvias, remover la tierra, abonar. No todos los hombres participan en el cuidado y manejo de los huertos que observamos. La participación más activa la realizan las mujeres y todas las actividades antes mencionadas ellas las realizan solas, además de incluir el traspaso de plantas, que muchas veces lo hacen en recipientes reciclados como cubetas rotas, ollas de metal, y botes de pet, los niños también participan en estas actividades ayudando a sus madres, son colectores de frutas maduras o hierbas.

El rol de la mujer dentro de las familias tradicionales está muy claro, existen antecedentes históricos sobre el papel de la mujer de cómo usan e identifican diversas plantas medicinales, ya que la salud es un papel importante para el bienestar de la familia, además, las mujeres son las encargadas y responsables del cuidado familiar y de la preparación de los alimentos (Cruz, 2016).

En el Cuadro 2 se ofrecen datos detallados de los encargados del cuidado y manejo del huerto familiar, de los 20 huertos muestreados se seleccionaron solo los huertos que tienen mayor producción de plantas alimentarias.

Tomando como referencia las entrevistas a profundidad, se obtuvo información que permitió construir la historia de vida de nuestros informantes y el aprovechamiento de las especies vegetales, los productos que se obtienen del huerto familiar contribuyen al autoabasto y disminuye la necesidad de comprar productos.

A pesar de ser una comunidad de origen campesino, nuestros informantes tienen profesiones y trabajos distintos:

Informante, HF3: Matrimonio joven originario de San Juan Tlacotenco con una hija de 7 años, cuentan con estudios de licenciatura en enfermería, trabajan para el IMSS en Cuernavaca en el área de urgencias.

Informante, HF 4: Informante es originaria de San Juan Tlacotenco, tiene 26 años y cuenta con el bachillerato terminado, ella reconoce varias palabras en náhuatl pero no lo habla en su totalidad, actualmente se dedica a la venta, en la entrada de 
Table 2. General information on those responsible for the care and management of the gardens in San Juan Tlacotenco

Cuadro 2. Información general de los responsables del cuidado y manejo de los huertos de San Juan Tlacotenco

\begin{tabular}{|c|c|c|c|c|c|c|c|}
\hline $\begin{array}{l}\text { Garden/ } \\
\text { Huerto }\end{array}$ & Sex / Sexo & $\begin{array}{l}\text { Age / } \\
\text { Edad }\end{array}$ & $\begin{array}{l}\text { Occupation/ } \\
\text { Ocupación }\end{array}$ & $\begin{array}{l}\text { Schooling/ } \\
\text { Escolaridad }\end{array}$ & $\begin{array}{l}\text { Language/ } \\
\text { Lengua }\end{array}$ & $\begin{array}{l}\text { Garden age/ } \\
\text { Edad del } \\
\text { huerto }\end{array}$ & $\begin{array}{c}\text { Who takes care } \\
\text { of the HG/Quien } \\
\text { se hace cargo } \\
\text { del HF }\end{array}$ \\
\hline $\mathrm{H} 1$ & $\begin{array}{l}\text { Female / } \\
\text { Femenino }\end{array}$ & 31 años & Nurse / Enfermera & Licenciatura & español & 60 años & $\begin{array}{l}\text { Husband and } \\
\text { informant/ } \\
\text { Esposo e } \\
\text { informante }\end{array}$ \\
\hline $\mathrm{H} 2$ & $\begin{array}{l}\text { Female / } \\
\text { Femenino }\end{array}$ & 27 años & $\begin{array}{l}\text { Merchant/ } \\
\text { Comerciante }\end{array}$ & $\begin{array}{l}\text { Bachelor's degree / } \\
\text { Bachillerato }\end{array}$ & Nahuatl & 60 años & $\begin{array}{l}\text { Informant/ } \\
\text { Informante }\end{array}$ \\
\hline H3 & $\begin{array}{l}\text { Female / } \\
\text { Femenino }\end{array}$ & 72 años & $\begin{array}{l}\text { Homemaker/ } \\
\text { Hogar }\end{array}$ & $\begin{array}{l}\text { Incomplete } \\
\text { elementary school / } \\
\text { Primaria trunca }\end{array}$ & Nahuatl & 10 años & $\begin{array}{l}\text { Informant/ } \\
\text { Informante }\end{array}$ \\
\hline $\mathrm{H} 4$ & $\begin{array}{l}\text { Female / } \\
\text { Femenino }\end{array}$ & 26 años & $\begin{array}{l}\text { Homemaker/ } \\
\text { Hogar }\end{array}$ & $\begin{array}{l}\text { Incomplete } \\
\text { high school/ } \\
\text { Preparatoria trunca }\end{array}$ & Nahuatl & 30 años & $\begin{array}{l}\text { Informant/ } \\
\text { Informante }\end{array}$ \\
\hline H5 & $\begin{array}{l}\text { Female / } \\
\text { Femenino }\end{array}$ & 30 años & $\begin{array}{l}\text { Homemaker/ } \\
\text { Hogar }\end{array}$ & $\begin{array}{l}\text { Technical-oriented } \\
\text { high school/ } \\
\text { Bachillerato }\end{array}$ & $\begin{array}{l}\text { Spanish / } \\
\text { Español }\end{array}$ & 7 años & $\begin{array}{l}\text { Informant/ } \\
\text { Informante }\end{array}$ \\
\hline $\mathrm{H} 6$ & $\begin{array}{l}\text { Female / } \\
\text { Femenino }\end{array}$ & 41 años & $\begin{array}{l}\text { Homemaker/ } \\
\text { Hogar }\end{array}$ & $\begin{array}{l}\text { Secondary school / } \\
\text { Secundaria }\end{array}$ & $\begin{array}{l}\text { Spanish / } \\
\text { Español }\end{array}$ & 30 años & $\begin{array}{l}\text { Whole family/ } \\
\text { Toda la familia }\end{array}$ \\
\hline $\mathrm{H} 7$ & $\begin{array}{l}\text { Female / } \\
\text { Femenino }\end{array}$ & 23 años & $\begin{array}{l}\text { Homemaker/ } \\
\text { Hogar }\end{array}$ & $\begin{array}{l}\text { Secondary school/ } \\
\text { Secundaria }\end{array}$ & $\begin{array}{l}\text { Spanish / } \\
\text { Español }\end{array}$ & 30 años & $\begin{array}{l}\text { Informant and } \\
\text { daughter-in-law / } \\
\text { Informante y } \\
\text { nuera }\end{array}$ \\
\hline $\mathrm{H} 8$ & $\begin{array}{l}\text { Male / } \\
\text { Masculine }\end{array}$ & 18 años & $\begin{array}{l}\text { Student/ } \\
\text { Estudiante }\end{array}$ & $\begin{array}{l}\text { Technical-oriented } \\
\text { high school/ } \\
\text { Bachillerato }\end{array}$ & Nahuatl & 30 años & $\begin{array}{l}\text { Whole family / } \\
\text { Toda la familia }\end{array}$ \\
\hline H9 & $\begin{array}{l}\text { Female / } \\
\text { Femenino }\end{array}$ & 54 años & $\begin{array}{l}\text { Homemaker/ } \\
\text { Hogar }\end{array}$ & $\begin{array}{l}\text { Elementary school / } \\
\text { Primaria }\end{array}$ & $\begin{array}{l}\text { Spanish / } \\
\text { Español }\end{array}$ & 34 años & $\begin{array}{l}\text { Whole family / } \\
\text { Toda la familia }\end{array}$ \\
\hline $\mathrm{H} 10$ & $\begin{array}{l}\text { Female / } \\
\text { Femenino }\end{array}$ & 20 años & $\begin{array}{l}\text { Homemaker/ } \\
\text { Hogar }\end{array}$ & $\begin{array}{l}\text { Technical-oriented } \\
\text { high school/ } \\
\text { Bachillerato }\end{array}$ & $\begin{array}{l}\text { Spanish / } \\
\text { Español }\end{array}$ & 20 años & $\begin{array}{l}\text { Informant } \\
\text { and mother/ } \\
\text { Informante y } \\
\text { madre }\end{array}$ \\
\hline $\mathrm{H} 11$ & $\begin{array}{l}\text { Male / } \\
\text { Masculine }\end{array}$ & 33 años & $\begin{array}{l}\text { Agricultural } \\
\text { technician / } \\
\text { Técnico } \\
\text { agropecuario }\end{array}$ & $\begin{array}{l}\text { Technical-oriented } \\
\text { high school/ } \\
\text { Bachillerato }\end{array}$ & $\begin{array}{l}\text { Spanish / } \\
\text { Español }\end{array}$ & 42 años & $\begin{array}{l}\text { Whole family / } \\
\text { Toda la familia }\end{array}$ \\
\hline $\mathrm{H} 12$ & femenino & 39 años & $\begin{array}{l}\text { Homemaker/ } \\
\text { Hogar }\end{array}$ & $\begin{array}{l}\text { Incomplete } \\
\text { technical-oriented/ } \\
\text { Bachillerato trunco }\end{array}$ & $\begin{array}{l}\text { Spanish / } \\
\text { Español }\end{array}$ & 45 años & $\begin{array}{l}\text { Informant } \\
\text { and children / } \\
\text { Informante y } \\
\text { hijos }\end{array}$ \\
\hline
\end{tabular}

Source: Data obtained during fieldwork / Fuente: Datos obtenidos durante el trabajo de campo

Mondays and Wednesdays. They also offer flowers, blackberries, nopales and mushrooms when in season and on Fridays they offer their products in the Ameyali Tlacualli organic market, where they take everything they can due to the demand for the quality of their products.

The knowledge that the people of the community of San Juan Tlacotenco have regarding the use of plants is transmitted from one generation su casa ella ha instalado una mesa donde vende diversos dulces, aguas, bebidas dulces, refrescos, palomitas y chicharrones, colores de madera, juguetes que compran los niños de la primaria, ella es la hija menor de 2 hermanos, su hermano mayor estudia la licenciatura en agropecuarias en la UAEM, en la misma casa viven sus abuelos y sus padres.

Las razones de contar con un huerto familiar, es por herencia cultural, la obtención de alimentos y 
to another, so the home gardens are spaces of great local, municipal and state importance since they are spaces that preserve cultural, phylogenetic, and botanical information on the geographical place and the community (Casas Otero-Arnaiz, A., PérezNegrón, E., \& Valiente-Banuet, A. 2007).

The families also experiment, during the productive life of the garden, by incorporating new plants, making grafts on trees, planting new vegetables and then verifying their adaptation to the climate and soil (Martínez, 2005). The exchange of vegetable, ornamental and fruit species in the community of San Juan Tlacotenco is a common practice, always seeking competitiveness and the best sales possible; in this sense, the diversity of plants in the gardens was quantified, recording a total of 303 plants reported in the 20 family gardens, of which 202 are introduced species and 101 are native ones (Figure 3).

\section{Women and their role in the family diet}

The knowledge acquired by constant transmission, from mothers to daughters, has allowed them to manage plant and animal diversity, which provides them with food to complete the family diet. The participation of women, who generate agricultural and food knowledge, is fundamental in the composition of the garden. Cano (2015) suggests that women are able to generate strategies for adapting wild plants in order to obtain flowers, stems, seeds and fruits to feed the family.

The management of home gardens by women represents a strategy for family food security, since in this way they have partially countered the effect of the economic crisis on their families. Shiva (2003) adds that the role of women in the family economy and subsistence is due to the fact that they market a portion of the garden's products, which favors the relationship and social cohesion between communities, thus contributing to the family's monetary income. The role of women is of vital importance because they have the ability to generate multiplier effects in the family. Photo 3 shows a woman from San Juan Tlacotenco cooking food.

The community of San Juan Tlacotenco has various food production systems, among them the
Figure 3. Origin status of the species reported during fieldwork in the home gardens of San Juan Tlacotenco Figura 3. Estatus de origen de las especies reportadas durante el trabajo de campo en los huertos familiares de San Juan Tlacotenco

Native and Introduced / Nativas e introducidas

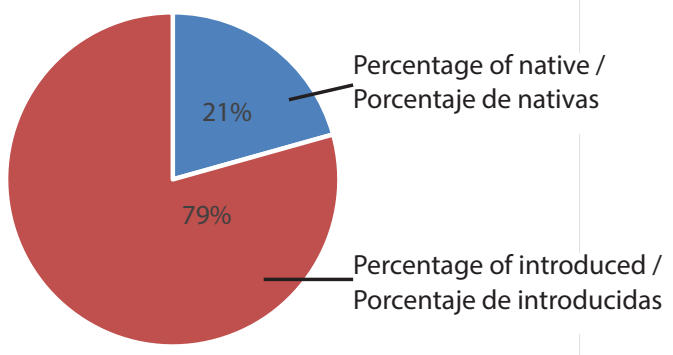

Source: Data obtained during fieldwork

Fuente: Datos obtenidos durante el trabajo de campo

los diversos aprovechamientos que los poseedores obtienen, que responden a la necesidad de cada familia, encontramos huertos con cultivos destinados para su venta, y valorados por sus características ornamentales de sus flores, y otros valorados por su producción alimentaria.

Informante HF 19: La familia cuenta con tierras de cultivo en la montaña, donde siembran diversos productos; papa, maíz, frijol, haba, nopal, avena forrajera. También se dedican a la crianza de borregos cabeza negra (sulfo) que venden como carne, también tienen vacas lecheras y de ellas extraen leche que venden, cuentan con 80 cajones de abejas, tres apiarios de 30; 30 y 20, la colecta de miel la realizan tres veces al año, la primera extracción la realizan en abril, después en noviembre y diciembre. El huerto provee a la familia de diverso, productos durante todo el año. La familia usa estos productos para alimentarse, el excedente es puesto a la venta en la cabecera municipal de Tepoztlán los lunes y miércoles, también ofrecen flores, zarzamoras, nopales, hongos, cuando es temporada y los días viernes ofrecen sus productos en el mercado orgánico Ameyali Tlacualli, ahí llevan todo lo que pueden, debido a la demanda de la calidad de sus productos.

El conocimiento que tienen las personas de la comunidad de San Juan Tlacotenco, respecto al uso 
Photo 3. Woman from the community of San Juan Tlacotenco, preparing food on her wood stove.

Foto 3. Mujer de la comunidad de San Juan Tlacotenco, preparando alimentos en su estufa de leña.

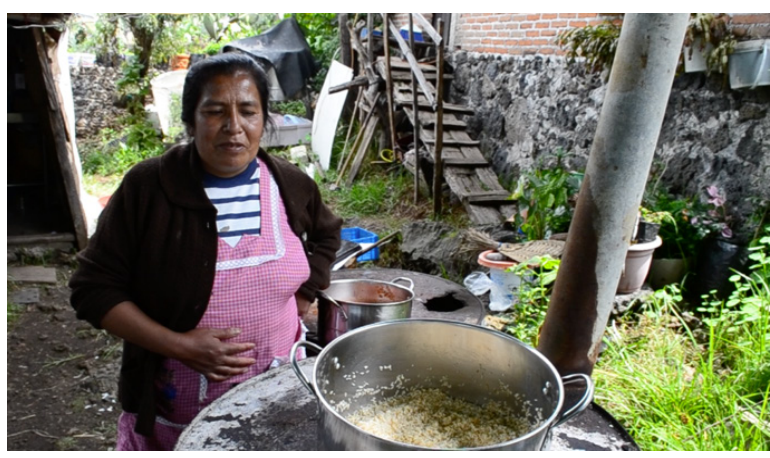

Source: Data obtained during fieldwork.

Fuente: Datos obtenidos durante el trabajo de campo.

home gardens, the milpa, and nopal cultivation; by tradition, there is still the collection of peripheral foods such as seasonal mushrooms. The most representative foods in the community's diet are nopal, tree pepper (chile manzano) and blackberry.

Nopal is a part of the community's basic diet. It is consumed in different forms with salt or sugar, it is not used as a garnish but as a dish, people eat it in soups, accompanied with eggs, in ceviche, raw, in juices, grilled, pickled, in tortita, in green sauce, fried, and prepared like cod; in its sweet form it is prepared in jam, dried in strips with chili and lemon, and used in tamarind candy balls.

Forty-one ingredients obtained during the year are used for the preparation of the various dishes. The list seems very short; however, some of the foods from the family garden that are still present give us elements for analyzing their importance to the community. The way the foods are consumed and combined with others helps to understand their role in the community of San Juan Tlacotenco, as well as the reasons for their continuing presence in the gardens. For example, nopal is present to a greater degree in the 20 home gardens, due to its cultural, food and economic importance to the community. Nopal cultivation in San Juan Tlacotenco began in 1970 and has been well accepted in the community because it survives with little water and is present throughout the year (Agenda Técnica Agrícola Morelos, 2015). The harvest is done by hand, which requires hard work, most of the de las plantas, es trasmitido de una generación a otra, por lo que los huertos familiares son espacios de gran importancia, local, municipal y estatal ya que son espacios que preservan información cultural, filogenética, botánica del lugar geográfico y de la comunidad (Casas Otero-Arnaiz, A., Pérez-Negrón, E., \& Valiente-Banuet, A. 2007).

Las familias también experimentan, durante la vida productiva del huerto, incorporar nuevas plantas, haciendo injertos en árboles, plantado nuevos vegetales verificando su adaptación al clima, tierra Martínez (2005). El intercambio de especies vegetales, ornamentales y frutales en la comunidad de San Juan Tlacotenco, es una práctica común, siempre se busca la competitividad y obtener las mejores ventas; en este sentido, la diversidad de plantas en los huertos se cuantifico en un total de 303 plantas reportadas en los 20 huertos familiares, 202 son especies introducidas y 101 nativas (Figura 3).

\section{Las mujeres y su papel en la alimentación familiar}

El conocimiento adquirido por trasmisión constante, de madres a hijas les ha permitido el manejo de diversidad vegetal y animal, lo que les proporciona alimento para completar la dieta. En la composición del huerto, es fundamental la participación de la mujer, que es generadora de conocimiento agrícola y alimentario, Cano (2015) sugiere que las mujeres son capaces de generar estrategias de adaptación de plantas silvestres, obtención de flores, tallos, semillas y frutos para la alimentación de la familia.

El manejo de los huertos familiares por parte de las mujeres representa una estrategia para la seguridad alimentaria de la familia, ya que de esta manera han resuelto parcialmente el efecto de crisis económica en sus familias, Shiva (2003) añade que el papel de la mujer en la economía y subsistencia familiar, se debe a que comercializa una parte de los productos del huerto, que favorece la relación y la cohesión social entre comunidades, contribuyendo de esta manera a los ingresos monetarios de la familia. El rol de la mujer es de vital importancia por contar con la capacidad de generar efectos multiplicadores en la familia. En la Foto 3, se muestra una mujer de San Juan Tlacotenco cocinando alimentos.

La comunidad de San Juan Tlacotenco, cuenta con diversos sistemas de producción de alimentos, 
community's production is sold in Cuernavaca and in the municipal market of the municipal capital of Tepoztlán, and women are in charge of marketing it; it is common to see them sell this product in and out of the market (Table 3).

According to these results, it can be seen that there is a greater use of uncooked than cooked food, and that they are intended to complement the daily diet of the families of San Juan Tlacotenco.

The home garden is beginning to undergo considerable changes for these families; it is becoming an ornamental garden, due to particular preferences. The economic demand for ornamental flowers is growing, which makes people more interested in them than in food. The demand for flowers is due to the patron saint festivals, which take place throughout the year. The eight neighborhoods of the municipal capital hold two such festivals annually; also, their traditions are linked to the beginning of the agricultural cycle from May-June, which demands the acquisition of flowers for offerings. The death of a community member is also an important factor in the demand for flowers, as this has been one of the reasons that has been documented concerning the preferences for these plants over others; the peasants see in these flowers the ability to earn a higher economic income and to better survive from one day to the next in their homes.

Table 4 shows some species of wild plants and animals that are no longer included in the diet of the San Juan Tlacotenco families and have been replaced by other plants in the family garden.

\section{Conclusion}

The use of food plants identified in the home gardens clearly shows their importance to the local food culture. However, this importance is diminishing due to changing preferences, the supply of external food products and the gradual loss of the food culture based on local resources. In spite of this uncertain scenario developing in relation to the home gardens of San Juan Tlacotenco, its inhabitants continue to carry out this practice and have managed to create systems adaptable to these transformations.

The multi-use natural resource strategy of the peasant families of San Juan Tlacotenco allows the making of dishes based on tradition and their own entre los que se destacan los huertos familiares, la milpa, el cultivo del nopal; por tradición aún existe la colecta de alimentos periféricos como los hongos de temporada. Los alimentos más representativos en la alimentación de la comunidad son el nopal, chile manzano y zarzamora.

El nopal, es una parte de la dieta básica de la comunidad, es consumido en distintas formas con sal o con azúcar, no es usado como guarnición sino como un platillo, las personas lo comen en sopas, acompañado con huevo, en ceviche, crudo, en jugos, asado, escabeche, en tortita, en salsa verde, frito, tipo bacalao y en su forma dulce es preparado en mermelada, deshidratado en tiritas con chile y limón, tarugos de nopal con tamarindo. En la época de lluvias es usado con cal para impermeabilizar casas de adobe.

Para la elaboración de los platillos se emplean 41 ingredientes, que se obtienen durante el año. La lista parece muy escasa, sin embargo, algunos de los alimentos del huerto familiar que aún están presentes nos dan elementos de análisis sobre la importancia para la comunidad. La forma en cómo se consumen y se combinan los alimentos con otros ayuda a comprender su papel en la comunidad de San Juan Tlacotenco, así como las razones de su permanencia aún en los huertos. Por ejemplo, el nopal está presente en mayor cantidad en los 20 huertos familiares, debido a su importancia cultural, alimentaria y económica para la comunidad. El cultivo de nopal en San Juan Tlacotenco se inició en el año 1970, y ha sido una planta bien aceptada en la comunidad ya que sobrevive con poca agua y está presente durante todo el año (Agenda Técnica Agrícola Morelos, 2015), la cosecha se realiza a mano, lo que requiere de un arduo trabajo, la mayoría de la producción de la comunidad es vendida en Cuernavaca y en el mercado municipal de la cabecera Municipal de Tepoztlán, la comercialización está a cargo de las mujeres, es común verlas vender este producto dentro y fuera del mercado (Cuadro 3).

De acuerdo con estos resultados se observa que existe un mayor aprovechamiento de alimentos sin cocinar que los cocinados, y que tienen como fin complementar la alimentación cotidiana de las familias de San Juan Tlacotenco.

El huerto familiar está empezando a sufrir cambios considerables para estas familias, se está 
Table 3. Species from the home garden.

Cuadro 3. Especies provenientes del huerto familiar.

\begin{tabular}{|c|c|c|c|}
\hline Núm. & Nombre científico/Scientific name & Ingrediente/Ingredient & Modo de consumo/ Consumption mode \\
\hline 1 & Anona cherimola & Chirimoya & Raw /Crudo \\
\hline 2 & Apium graveolens & Celery /Apio & Raw and cooked/Crudo y cocinado \\
\hline 3 & Beta vulgaris & Beet /Betabel & Raw and cooked/Crudo y cocinado \\
\hline 4 & Capsicum pubescens & Tree pepper /Chile manzano & Raw and cooked/Crudo y cocinado \\
\hline 5 & Casimiroa edulis & White sapote /Zapote blanco & Raw /Crudo \\
\hline 6 & Citrus reticulata & Mandarin /Mandarina & Raw /Crudo \\
\hline 7 & Citrus sinensis & Orange /Naranja & Raw/Crudo \\
\hline 8 & Citrus x latifolia & Lemon /Limón & Raw/Crudo \\
\hline 9 & Crataegus mexicana & Tejocote & Raw and cooked/Crudo y cocinado \\
\hline 10 & Cucurbita ficifolia & Chilacayote/Fig-leaf gourd & Cooked / Cocinado \\
\hline 11 & Cucurbitapepo & Calabaza/Squash & Cooked / Cocinado \\
\hline 12 & Eriobotryajaponica & Níspero/Loquat & Raw /Crudo \\
\hline 13 & Ficus carica & Higo/Common fig & Raw /Crudo \\
\hline 14 & Fragaria chiloensis & Fresa/Strawberry & Raw /Crudo \\
\hline 15 & Hylocereus undatus & Pitaya/Pitahaya & Raw /Crudo \\
\hline 16 & Ingajinicuil & Cajenecuil/Ice cream bean & Raw /Crudo \\
\hline 17 & Ipomea batata & Camote/Sweet potato & Raw and cooked/Crudo y cocinado \\
\hline 18 & Malus domestica & Apple /Manzana & Raw /Crudo \\
\hline 19 & Mangifera indica & Mango & Raw /Crudo \\
\hline 20 & Morus celtidifolia & Texas mulberry /Mora & Raw and cooked/Crudo y cocinado \\
\hline 21 & Morus nigra & Black mulberry /Mora & Raw and cooked/Crudo y cocinado \\
\hline 22 & Musa paradisiaca & Banana /Plátano & Raw /Crudo \\
\hline 23 & Opuntia ficus-indica & Nopal & Cooked / Cocinado \\
\hline 24 & Lactuca sativa & Lettuce /Lechuga & Raw / Crudo \\
\hline 25 & Passiflora edulis & Passion fruit /Maracuyá & Raw/Crudo \\
\hline 26 & Passiflora ligularis & Granadia /Granada china & Raw/ Crudo \\
\hline 27 & Persea americana & Avocado /Aguacate & Raw/Crudo \\
\hline 28 & Phaseolus vulgaris & Common bean /Frijol peruano & Cooked / Cocinado \\
\hline 29 & Prunus persica & Peach /Durazno & Raw and cooked/Crudo y cocinado \\
\hline 30 & Prunus serótina subsp. capulli & Black cherry/Capulín & Raw and cooked/Crudo y cocinado \\
\hline 31 & Punica granatum & Pomegranate / Granada roja & Raw /Crudo \\
\hline 32 & Pyrus communis & Pear /Pera & Raw and cooked/Crudo y cocinado \\
\hline 33 & Raphanus sativus & Radish / Rábano & Raw /Crudo \\
\hline 34 & Rubus aderotrichus & Blackberry /Zarzamora & Raw and cooked/Crudo y cocinado \\
\hline 35 & Rubus idaeus & Raspberry /Frambuesa & Raw/Crudo \\
\hline 36 & Sechium edule & Chayote & Raw and cooked/Crudo y cocinado \\
\hline 37 & Solanum tuberosum & Potato /Papa & Cooked / Cocinado \\
\hline 38 & Spondia purpurea & Plum /Ciruela & Raw /Crudo \\
\hline 39 & Taraxacum sp & Dandelion /Prima del diente de león & Raw /Crudo \\
\hline 40 & Vicia faba & Broad bean /Haba & Cooked / Cocinado \\
\hline 41 & Zeamays & Criollo corn /Maíz criollo & Cooked / Cocinado \\
\hline
\end{tabular}

Source: Author-made from fieldwork

Fuente: Elaboración propia a partir del trabajo de campo 
Table 4. Food species that are no longer grown in the family gardens of San Juan Tlacotenco Cuadro 4. Especies alimentarias que ya NO son cultivadas o consumidas en los Huertos familiares de San Juan Tlacotenco

\begin{tabular}{|c|c|}
\hline $\begin{array}{l}\text { Food species that are no longer grown in home gardens (without ID)/ } \\
\text { Especies alimentarias que ya no se cultivan en los huertos familiares (sin ID) }\end{array}$ & Procedencia / Origin \\
\hline Pea/Chícharo & Home garden / Huerto familiar \\
\hline Criollo ball avocado/Aguacate bola (criollo) & Home garden / Huerto familiar \\
\hline Quelite chipili & Home garden / Huerto familiar \\
\hline Radish/Rábano & Home garden / Huerto familiar \\
\hline Huauzontle & Home garden / Huerto familiar \\
\hline Cowpea (pink color)/Frijol chino (color rosa) & Home garden / Huerto familiar \\
\hline Bean / Yepatlache (lilac color)/Frijol/yepatlache (color lila) & Home garden / Huerto familiar \\
\hline Bolivian coriander/Pipiska & Home garden / Huerto familiar \\
\hline Quiote flower / Flor de quiote & Forest / Bosque \\
\hline Squash flower/Flor de calabaza & Home garden / Huerto familiar \\
\hline Hojas de colorín/chompantle/Colorin /chompantle leaves & Home garden / Huerto familiar \\
\hline Fodder oats/Avena forrajera & Home garden / Huerto familiar \\
\hline Foreign red potato/Papa roja extranjera & Home garden / Huerto familiar \\
\hline Tepecilantro (wild, round-leaved coriander)/Tepecilantro (cilantro silvestre, hoja redonda) & Forest / Bosque \\
\hline Huaspepeton (germinated Gourd seeds) / Huaspepeto/semillas de guaje germinadas & Home garden / Huerto familiar \\
\hline Gourd, Tejon /Guaje & Home garden / Huerto familiar \\
\hline Tejón & Traditional hunting / Cacería tradicional \\
\hline Wild birds / Aves silvestres & Traditional hunting / Cacería tradicional \\
\hline Wild wasp honey / Miel silvestre de avispa & Forest / Bosque \\
\hline Wild bee honey/Miel silvestre de abeja & Forest / Bosque \\
\hline
\end{tabular}

Source: Author-made based on fieldwork

Fuente: Elaboración propia a partir del trabajo de campo

culinary legacy, where the networks of exchange with neighbors help the heads of household provide sufficient inputs for food preparation.

For all the above reasons, the home gardens of San Juan Tlacotenco contribute elements that help to understand, revalue and preserve ancestral knowledge regarding phytogenetic and cultural resources of the food that has remained despite the evident change.

\section{Acknowledgments}

The authors are grateful for the support provided by CONACyT 2016-2019.

End of English version convirtiendo en jardín de ornato, debido a las preferencias particulares. La demanda económica de las flores de ornato está creciendo, lo cual hace que las personas tengan mayor interés en ellas, que en las alimenticias. La demanda de flores se debe a las fiestas patronales, que se dan durante todo el año, los ocho barrios de la cabecera municipal realizan dos fiestas anuales, también el arraigo a sus tradiciones durante el inicio del ciclo agrícola que es de mayo-junio, demanda la adquisición de flores para las ofrendas., el deceso de algún miembro de la comunidad, también es factor importante de la demanda de flores, esta ha sido una de las razones que se han documentado, sobre las preferencias de estas plantas hacia otras, en ellas ven mayores ingresos económicos y sobrellevar el día al día en sus hogares.

En el Cuadro 4 se muestran algunas especies de plantas y animales silvestres que ya NO son incluidas 


\section{References/Referencias}

Aguilar Piña, P. (2014). Cultura y alimentación. Aspectos fundamentales para una visión comprensiva de la alimentación humana. Anales de Antropología.,48-I, 11-31.

Agenda Técnica Agrícola Morelos. (2015). SAGARPA, SENASICA, INIFAP, México.

Álvarez A. M., C., Olguín P., A., Asiain H., G., Alcántar G., \& Castillo M., A. (2001). Biotecnificación de solares familiares de las zonas bajas tropicales. Terra Latinoamericana. Universidad Autónoma Chapingo. 19 (1):37-46 pp.

Bertran Vilá, M. (2005) Cambio alimentario e identidad de los indígenas mexicanos México. Publicaciones y Fomento Industrial, UNAMCentro de Investigaciones Multidisciplinarias en Ciencias y Humanidades, y México Nación Multicultural, Programa Universitario.

Cahuich-Campos, D. (2012). El huerto maya y la alimentación cotidiana de las familias campesinas de X-Mejía, Hopelchén, Campeche, en el libro El huerto familiar del sureste de México, Editor. Ramón Mariaca Méndez. Secretaría de Recursos Naturales y Protección Ambiental del Estado de Tabasco. El Colegio de la Frontera Sur.

Cano Ramírez, M., de la Tejera, B., Casas, A., Salazar, L., \& García B., R. (2012). Migración rural y huertos familiares en una comunidad indígena del centro de México. Botanical Sciences 90 (3) 287-304.

Cano Contreras, E. (2015). Huertos familiares: un camino hacia la soberanía alimentaria. Revista Pueblos y fronteras digital. ISSN 1870-4115, Volumen 10, número 20.

Cruz Yáñez, L. A. (2016). El papel de las mujeres en los huertos familiares. Alternativas en psicología. Número 36. Noviembre.

Casas, A., Otero-Arnaiz, A., Pérez-Negrón, E., \& Valiente-Banuet, A. (2007). In situ management and domestication of plants in Mesoamerica. Annals of Botany. Oct, 100(5): 1101-1115.

Estrada Lugo, E., Bello B. E., \& Serralta Peraza, L. (1998). Dimensiones de la etnobotánica: el solar maya como espacio social. En: Cuevas S. J. A., Cedillo P., E., Muñoz O. A. y Vera C. P. (Eds.). Lecturas en Etnotánica. Publicaciones del Programa Nacional de Etnobotánica. Universidad Autónoma Chapingo. en la alimentación de las familias de San Juan Tlacotenco y que ha sido sustituidas por otras plantas en el huerto familiar.

\section{Conclusión}

El uso de plantas alimentarias identificadas en los huertos familiares, ponen en evidencia su importancia para la cultura alimentaria local; aunque esta importancia se encuentre en orden decreciente en preferencia, aunado a la oferta de productos alimentarios externos y la pérdida gradual de la cultura alimentaria basada en los recursos locales. Sin embargo, a pesar de este panorama incierto que se desarrolla con relación a los huertos familiares de San Juan Tlacotenco, sus habitantes siguen llevando a cabo esta práctica y han logrado crear sistemas adaptables a estas trasformaciones.

La estrategia de usos múltiples de recursos naturales de las familias campesinas de San Juan Tlacotenco, permite la elaboración de platillos basados en una tradición y legado culinario propio, donde las redes de intercambio con los vecinos ayudan a que las jefas de familia prevean insumos suficientes para la preparación de alimentos.

Por todo lo anterior, los huertos familiares de San Juan Tlacotenco, aportan elementos que coadyuvan a la comprensión, la revalorización y preservación del conocimiento ancestral referente a los recursos fitogenéticos y culturales, de los alimentos que han permanecido a pesar del evidente cambio.

\section{Agradecimientos}

Al apoyo otorgado por el CONACyT 2016-2019

Fin de la version en español

Garine, I., \& Vargas, L. A. (1997). Introducción a las investigaciones antropológicas sobre alimentación y nutrición. Cuadernos de nutrición. No.20(3):21-28.

Greeberg, L. S. (2003). Women in the garden and kitchen: The role of cuisine in the conservation of traditional house lot crops among Yacatec Mayan immigrants. En: PL Howars (eds.). Women and plants: Gender relations in biodiversity management and conservation. Zed Books, UK, GTZ Germany e IDRC Canada: 51-65. 
Hernández Xolocotzi, E. (1976). Agroecosistemas de México: contribuciones a la enseñanza, investigación y divulgación agrícola. Colegio de Posgraduados. Chapingo, Estado de México. 559.

Kumar, B. M., \& Nair, P. K. R. Eds. (2006). Tropical homegardens: a time-tested example of sustainable agroforestry. Agroforestry. Vol. 3. Springer, Netherlands.

Levi-Strauss, C. (1964). Mitológicas I. Lo crudo y lo cocido. México: Fondo de Cultura Económica.

Lewis, O. (1968). Tepoztlán un pueblo de México, Editorial Joaquín Mortiz. S. A.

Mariaca Méndez, R., González-Jácome, A., \& Lerner Martínez, T. (2007). El huerto familiar en México; Avances y propuestas, en Jesús Francisco, López Olguín, Agustín Aragón García, Ana María Tapia Rojas (eds.), Avances en agroecología y ambiente, vol. I, México, Universidad Autónoma de Puebla, pp. 119-138.

Madrigal Uribe, D., \& Pérez, J. I. J. (2005). Huertos, diversidad y alimentación en una zona de transición ecológica del estado de México. Ciencia Ergo Sum, vol. 12, núm. 1, marzo-junio, pp. 54-63. Universidad Autónoma del Estado de México, Toluca, México.

Martínez Bustamante, R. (2005). Los huertos: una estrategia para la subsistencia de las familias campesinas. Anales de Antropología. Volumen 39-11. Instituto de Investigaciones Antropológicas, UNAM.

Meléndez Torres, J. M., \& Cañez de la Fuente, G. M. (2009). La cocina tradicional regional como un elemento de identidad y desarrollo local. El caso de San Pedro el Saucito, Sonora, México. Estudios Sociales. Número especial:184-204.

Nair P., K. R. 2001. Do tropical home gardens elude science, or is it the other way around. Agroforestry Sytems. 53: 239-245.
Pérez Izquierdo, J. O. (2011). Cambios en la alimentación de dos comunidades mayas del estado de Yucatán, elementos para una política integral de Educación Nutricional. Tesis Doctoral, El Colegio de la Frontera Sur (ECOSUR), Campeche, Campeche, México.

Pérez Vázquez, A., Cuanalo, H., \& Sol Sánchez.

Robles, B. (2011). La entrevista en profundidad: una técnica útil dentro del campo atropofísico. Revista Cuicuilco. Vol. 18. No.52., sep-dic, México.

Programa de Manejo del Parque Nacional el Tepozteco. (2018). http://conanp.gob.mx abiertos/DGCD/100.

Vandana, S. (2003). Cosecha robada el secuestro del suministro mundial de alimentos. Editorial Paidós, Barcelona, España.

Solís Becerra, C. G. (2013). Hierbas comestibles y prácticas culinarias: el sistema huerto familiar en el Colectivo Mujeres y Maíz en Teopisca, Chiapas. Tesis de Maestría, El Colegio de la Frontera Sur (ECOSUR), San Cristóbal de las Casas, Chiapas.

Strauss-Lévi. (2002). Mitológicas II. De la miel a las cenizas. México, D. F., FCE.

Vargas Guadarrama, L., \& Casillas, L. (1990). La alimentación en México durante los primeros años de la colonia. Fernando Martínez Cortés (Ed. general): Historia general de la Medicina en México. Tomo2, Medicina Novohispana, Siglo $\mathrm{XVI}$, México, Academia Nacional de Medicina y Facultad de Medicina, UNAM: 78-90.

Vargas Guadarrama, L., \& Águila, P. (2002). Una visión integral de la alimentación: cuerpo, mente y sociedad. Cuadernos de Nutrición. Vol. 25. Núm. 2. marzo-abril. 